\title{
MAGNETIC RESONANCE SPECTROSCOPY IN THE DIAGNOSIS AND ETIOLOGICAL DEFINITION OF BRAIN BACTERIAL ABSCESSES
}

\author{
Lívia Tavares Morais', Verônica de Araújo Zanardi², Andréia Vasconcellos Faria²
}

\begin{abstract}
We report two patients with bacterial brain abscesses whose etiological diagnosis was correctly proposed by association of diffusion weighted images (DWI) and magnetic resonance spectroscopy (MRS) with conventional MRI. Both patients presented ring enhancing lesions with evidences of restricted diffusion. On MRS, the abscess caused by aerobic bacteria presented lactate and aminoacids peaks and the abscess caused by anaerobic facultative bacteria showed also acetate and succinate peaks. These results are in agreement with an unique previous study that related MRS pattern with bacterial etiology. Conventional MRI, associated with DWI and MRS is effective in diagnosing bacterial abscess and promising in exploring its etiology.
\end{abstract}

KEY WORDS: pyogenic bacterial abscess, spectroscopy, diffusion, magnetic resonance.

\begin{abstract}
Espectroscopia por ressonância magnética no diagnóstico e definição etiológica dos abscessos bacterianos cerebrais

RESUMO - Apresentamos dois pacientes com abscessos bacterianos cerebrais cujos diagnósticos etiológicos foram corretamente auxiliados pela associação de difusão e espectroscopia à ressonância magnética convencional. Ambos apresentavam lesões com captação anelar de contraste e evidências de restrição à difusão de moléculas de água. Na espectroscopia, o abscesso causado por bactéria aeróbia apresentou picos de lactato e aminoácidos, enquanto o abscesso causado por bactéria anaeróbia facultativa mostrou, além destes, picos de acetato e succinato. Tais resultados concordam com um único estudo prévio que relacionou o padrão de espectroscopia nos abscessos com sua etiologia bacteriana. A ressonância magnética convencional, associada à difusão e à espectroscopia é uma técnica eficiente no diagnóstico de abscessos bacterianos e promissora em explorar suas etiologias.
\end{abstract}

PALAVRAS-CHAVE: abscesso cerebral piogênico, espectroscopia, difusão, ressonância magnética.

\begin{abstract}
Abscesses can be defined as focal suppurative processes within the brain parenchyma and have been reported to account for $1 \%-2 \%$ and up to $8 \%$ of all intracranial space-occupying lesions in patients in developed and developing countries, respectively'. Instead of the fact that general abscess are usually diagnosed by conventional magnetic resonance images (MRI), some bacterial abscesses may have a nonspecific clinical and morphological presentation, simulating those of cystic ring-enhancing mass lesions of varying etiologies'. So, bacterial abscess may be misdiagnosticated as inflammation caused by other etiologies, as fungical, granulomatous or even as necrotic tumors ${ }^{2}$.

However, some particular details in conventional MRI may suggest the diagnosis and coupling diffusion weighted images (DWI) with magnetic resonance spec-
\end{abstract}

troscopy (MRS) has been explored by other authors to improve diagnostic specificity in focal brain lesions by enabling better lesion characterization'. Besides, it may be possible to explore the etiologies of bacterial brain abscesses, differentiating anaerobic from other pyogenic abscess (ie, aerobic or sterile) on the basis of metabolite patterns seen with in vivo MRS'.

Herein, we demonstrate that MRS coupled with DWI and structural MRI is helpful on characterize the etiology of bacterial abscess once the MRS pattern shows the metabolic products of specific bacterial groups.

\section{METHOD}

Patients - Patient 1 is a 16 years old male patient, with headache, fever and alteration in behavior that began 2

Department of Radiology, Faculty of Medical Sciences, State University of Campinas (UNICAMP), Campinas SP, Brazil: 'Undergraduate student; ${ }^{2}$ Assistant Professor.

Received 25 April 2007, received in final form 15 August 2007. Accepted 15 September 2007.

Dra. Andréia Vasconcellos Faria - Dept. Radiologia / Faculdade de Ciências Médicas - UNICAMP - Caixa Postal 6111 - $13083-970$ Campinas SP - Brasil. E-mail: andreia@fcm.unicamp.br 
weeks before. He had a previous head trauma and subsequent cerebrospinal fluid (CSF) fistula with spontaneous regression. MRI showed a left frontal lesion.

Patient 2 is a 58 years old male patient with diagnosis of Osler-Weber-Rendu disease since he was seven. He presented with 10 days headache. MRI showed a right temporal lesion.

Procedures - MRIs were performed in a 2T scanner (EIscint Prestige ${ }^{\circledR}$, Haifa, Israel), with $\mathrm{T}_{1}$ and $\mathrm{T}_{2}$ acquisitions in three orthogonal planes, including T1-weighted "spin echo" (SE) gadolinium enhanced images. MRI acquisition parameters were: sagittal T1 SE, $6 \mathrm{~mm}$ thick, flip angle $=180^{\circ}$; repetition time $(T R)=430$, echo time $(T E)=12$, matrix $200 \times 350$, field of view $(F O V)=25 \times 25 \mathrm{~cm} ; T_{2}$ and proton density "fast spin echo" (FSE), $6 \mathrm{~mm}$ thick, flip angle $=160^{\circ} ; \mathrm{TR}=4800$, $\mathrm{TE}=108 / 18$, matrix $256 \times 256, \mathrm{FOV}=22 \times 22 \mathrm{~cm}$ and T2- fluid-attenuated inversion recovery (FLAIR),TR $=8500$ and 2000 or 100 and $2200, T E=72$ or 90 , matrix of $256 \times 296$ and FOV of $22 \times 22 \mathrm{~cm}$. T1 SE gadolinium enhanced images were obtained in the 3 orthogonal planes. DWls were aqquired with TR/ $\mathrm{TE}=500 / 107 \mathrm{~ms}$, flip angle $=180^{\circ}, 6 \mathrm{~mm}$ thick, gap $=20 \%$, matrix $128 \times 128, F O V=37.3 \times 23.1 \mathrm{~cm}, 1$ nex, with 3 orthogonal gradients, $B=0-700 \mathrm{~s} / \mathrm{mm}^{2}$.

Single voxel hydrogen magnetic resonance spectroscopy (MRS) was acquired using PRESS sequence (TR/TE $=500 / 135$ $\mathrm{ms}$, number of excitation $((\mathrm{NEX})=200)$ with regions of interest (ROIs) of $8 \mathrm{~cm}^{3}$, centered in the lesions. Prior to the ac- quisition, a localized shimming at the ROI was performed, followed by water suppression adjustment. Localized shimming was repeated to ensure good field homogeneity and until the ${ }^{1} \mathrm{H}$ signal from water within the ROI became as narrow as possible. The spectra were post-processed using software supplied by the machine manufacturer (Elscint Prestige 2T, Haifa, Israel).

\section{RESULTS}

Both lesions were hyperintense in $\mathrm{T}_{2}$ weighted images (WI) and FLAIR and hypointense in T1WI with a ring of hyperintense signal on $\mathrm{T} 1 \mathrm{Wl}$ and hypointense signal on $\mathrm{T} 2 \mathrm{WI}$, with contrast peripheral enhancement and extensive surrounding edema (Fig 1).

DWI showed hyperintensity in both with a low signal in apparent coefficient diffusion (ADC) map (Fig 2). MRS showed many differences between the lesions. Patient 1 had aminoacid peak (0.9 ppm) and elevated lactate signal intensity (1.3 ppm) while patient 2 had a succinate (1.9 ppm) and acetate (2.4 ppm) peaks and also elevated lactate signal intensity (1.3 ppm) (Fig 3).

The lesions were surgically removed and culture revealed infection by Streptococcus pneumoniae, aer-
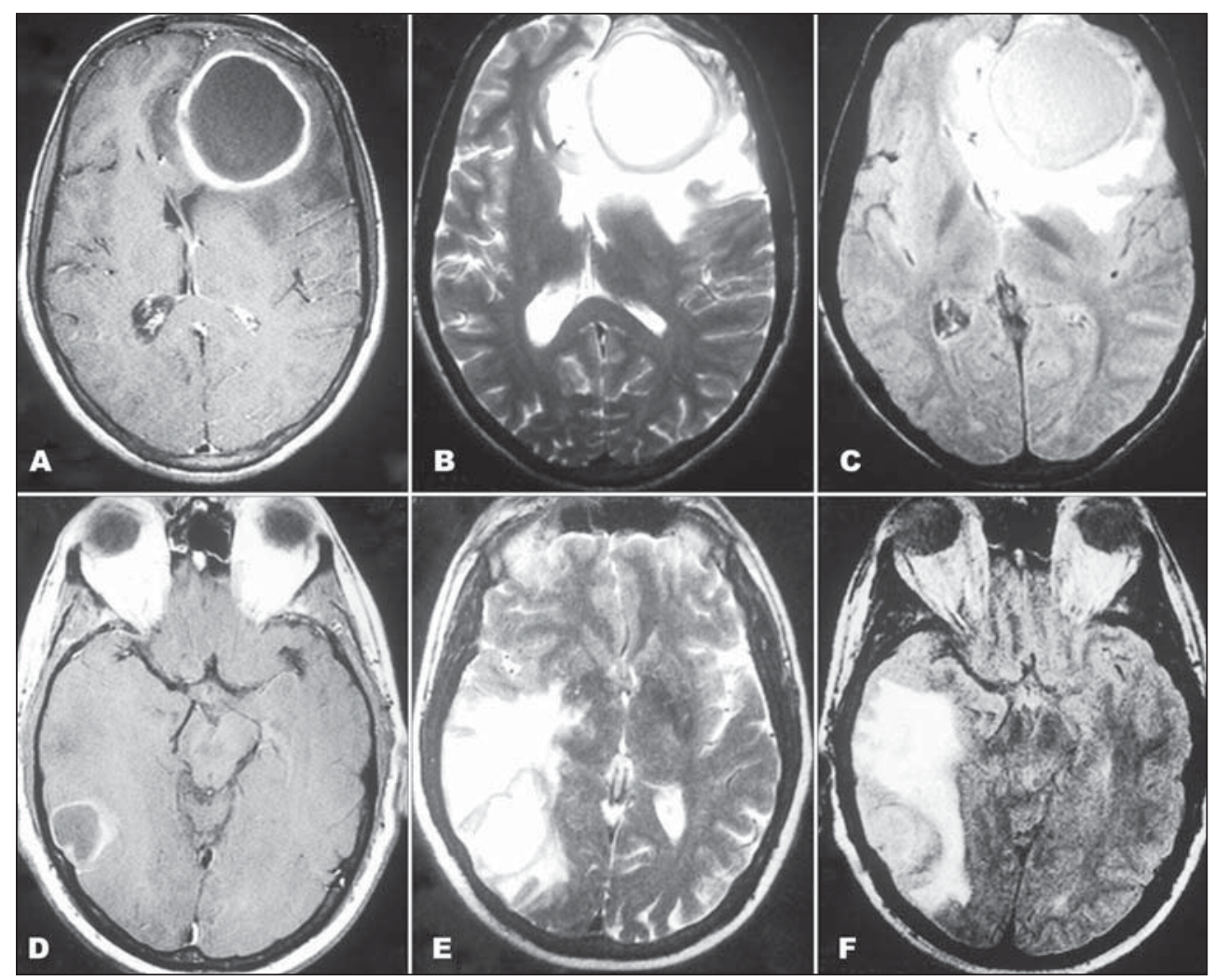

Fig 1. Large frontal rounded lesion in patient $1(A, B, C)$ and temporal lesion in patient $2(D, E, F)$ both with similar signals: hyperintense with hypointense halo in $T_{2}(A$ and $D)$ and FLAIR ( $B$ and E), hypointense in $T_{1}$ with peripheral enhancement ( $C$ and $\left.F\right)$. Both are surrounded by extensive edema with mass effect. 

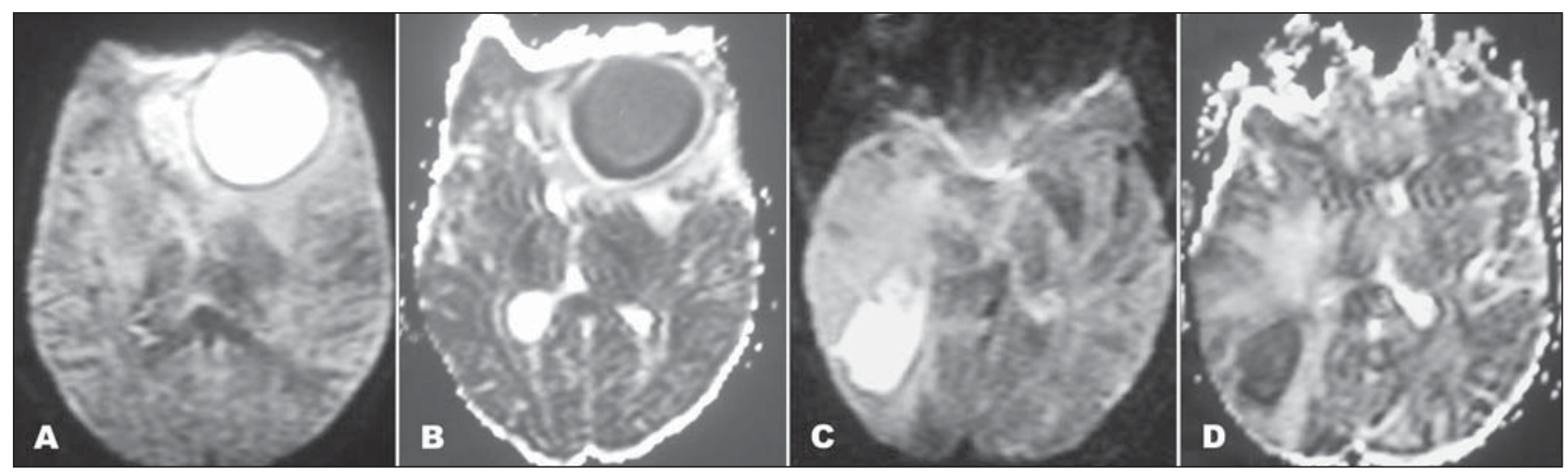

Fig 2. Patient $1(A$ and $B)$ and patient $2(C$ and $D)$ show lesions with restricted diffusion on DWI $(A$ and $C)$ and $A D C$ map $(B$ and $D)$.
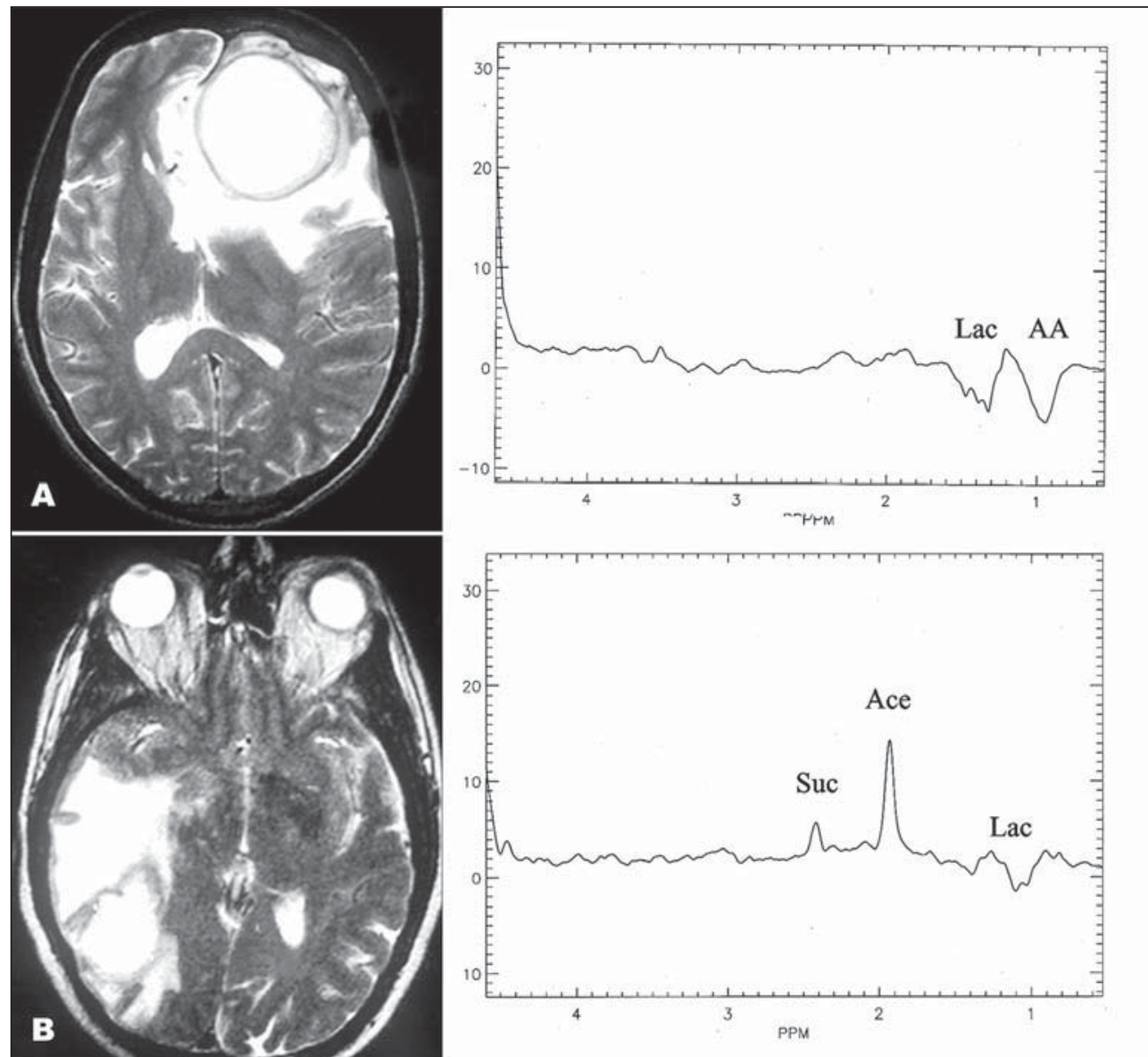

Fig 3. Proton MRS. Patient 1 (A) shows aminoacid peak (AA) and elevated lactate signal intensity (Lac), inverted in TE of $135 \mathrm{~ms}$ which makes it easy to differentiate from lipids signal. Patient 2 (B) had succinate (SUC) and acetate (Ace) peaks and also elevated lactate and aminoacid signal intensity. Both MRS performed in necrotic area display absence of characteristic peaks of brain tissue.

obe bacteria, in patient 1 and Streptococcus milleri, facultative anaerobe bacteria, in patient 2.

\section{DISCUSSION}

Abscesses usually are hyperintense in $\mathrm{T} 2 \mathrm{WI}$ and hypointense in T1Wl (as the most part of brain lesions) but bacterial abscesses have a particular con- tinuous peripheral ring hypointense on $\mathrm{T}_{2} \mathrm{Wl}$ and and hyperintense on $\mathrm{T} 1 \mathrm{Wl}$, a feature that could relate to coagulative necrosis, increased accumulation of hemorrhagic products and paramagnetic materials such as iron, magnesium and manganese ${ }^{3}$, and production of free radicals, secondary to bacterial metabolism ${ }^{4}$. Unfortunately, some tumors and frequently fungical or 
granulomatous abscesses (as occur in tuberculosis) 5, 6 present hemorrhagic areas producing the same alteration in peripheral signal intensity, making this finding suggestive of bacterial etiology, but nonspecific.

In addition to conventional MRI, DWI appears to be almost characteristic of bacterial abscesses. Pus is a viscous fluid content of inflammatory cells, mucoid protein, bacteria and necrotic tissue. Microscopic diffusion movement of water molecules are expected to be decreased in the cavity containing pus, whereas in necrotic tumor or cystic metastases, the cystic contents are less viscous, containing less inflammatory cells and more serous fluid ${ }^{7,8}$. So, bacterial abscess produce high signal on DWI and low ADC values, ranged from 0.45 to $0.8^{9}$. This variation might be related to a difference in the concentration of inflammatory cells, and differences in necrotic tissue debris, bacteria, and viscosity of abscess fluid ${ }^{8-10}$. Other inflammatory processes as fungical disease, toxoplasmosis and necrotic portions of the tumors usually show lower signal intensity on DWI and higher ADCs ${ }^{11}$.

However, recent studies have shown that restricted diffusion value is an important sign but is not specific for cerebral abscess. Restricted diffusion has been found in metastatic squamous cell carcinoma and radiation necrosis. The underlying pathophysiology is not known but probably due to sterile liquefaction necrosis. In sterile liquefaction necrosis, it may contain creamy pus like material with polymorphonuclear leukocytes ${ }^{12}$.

Not enough, MRS also may corroborate the diagnosis of bacterial abscess and progress in etiological diagnosis. MRS is a noninvasive method to access, in vivo, the biochemical environment of a tissue producing direct or indirect information about the mechanisms of the disease progression and /or the host reaction to the aggression factor. Clinically, it may help to define the nature of different types of brain lesions by the metabolic profile. In some cases, it helps the differentiation among infections from other etiologies when conventional MR images are incomplete or inconclusive ${ }^{13}$.

Bacterial abscesses are completely necrotic lesions and so, all metabolites that characterize the SNC tissue are absent if the region of interest (ROI) is full located in the necrotic center. In fact, in both patients reported, peaks that characterize brain, as $\mathrm{N}$-acetyl aspartate (NAA), considered a neuronal and axonal marker; choline, a constituent metabolite of cell membrane and myelin; and creatine, which plays a major role in energy metabolism, are absent ${ }^{14}$.
Lactate, an end product of anaerobic glycolysis and a considered marker of hypoxia, is elevated in both patients (identified as a reversed J coupled peak in 1.3 ppm in this applied TE (135 ms), that avoid lipid overlap). However, its elevation is nonspecific. Large lactate peaks have been commonly identified in necrotizing high-grade neoplasms, infarcts, demyelinating disease, encephalitis, cystic gliomas and in no pyogenic abscesses including toxoplasmosis ${ }^{15}$.

Other peaks, indicative of abnormal tissue were identified. Both patients showed amino-acid signals at 0.9 ppm, seen in many brain abscesses and assigned to valine, leucine, and isoleucine, considered representing accumulated end-products of proteolysis caused by proteolytic enzymes secreted by microorganisms or polymorphonuclear leukocytes in pus, or both $^{16-22}$. Patient 2, infected by an anaerobe facultative bacteria, presented acetate and succinate, considered being the end products of homolactic and heterolactic fermentation and key markers of bacterial infection ${ }^{23-25}$. Other infectious diseases as cysticercosis may also display succinate elevation ${ }^{26}$.

Garg et al. ${ }^{1}$, in an in vivo and in vitro study of 75 patients with brain abscess, also demonstrated differences in MRS according to bacterial etiology. Succinate and/or acetate were present in anaerobic infection. Latter, Lai et al. ${ }^{27}$ showed the same findings in MRS performed in low and high magnetic fields ${ }^{28}$. These metabolite resonances are probably the result of enhanced glycolysis and the fermentative pathways for energy generation ${ }^{4}$.

Results of studies focused on bacterial metabolism suggest that glycolysis is the universal cycle, irrespective of the aerobic or anaerobic nature of the bacteria. The pyruvate from glycolysis may enter into the tricarboxylic acid cycle in aerobes and in facultative anaerobes in the presence of oxygen. Alternatively, the pyruvate may follow the anaerobic fermentative route in anaerobes, where it may undergo carboxylation to form succinate via oxaloacetate, malate, and fumarate; and part of the pyruvate also forms acetate. The involvement of alternative anaerobic pathways for energy demands during acetate and succinate production by anaerobic bacteria may cause the appearance of these resonances in anaerobic abscesses. On the other side, the absence of acetate and succinate in the spectra of the patients with aerobes and facultative anaerobes can be explained by the fact that the pyruvate from glycolysis follows the tricarboxylic acid cycle. Although succinate is one of the intermediate metabolites of the tricarboxylic acid cycle it does not accumulate during its formation and immediately 
transforms to the next intermediate compound. This phenomenon could result in the absence of succinate in the spectra of aerobe ${ }^{29}$. Succinate was also earlier described as a marker for anaerobic infections in clinical samples at gas liquid chromatography ${ }^{25}$.

Beyond MRS represents a potential tool for noninvasive diagnosis of brain abscesses, it might be useful for evaluating changes after treatment. With effectiveness of antibiotic therapy, a decreasing of these abnormal peaks, produced by infectious organism and intense host inflammatory reaction, and the lactate signal persists ${ }^{30}$, besides the changes in signal and retraction of lesion at conventional MRI.

In conclusion, MRS coupled with structural MRI and DWI and MRS is effective and promising not only to diagnosing but also to explore the etiology of bacterial abscesses. In addition, it also may be a powerful tool to control the response to the treatment.

\section{REFERENCES}

1. Garg M, Gupta RK, Husain M, et al. Brain abscesses: etiologic categorization with in vivo proton MR spectroscopy. Radiology 2004;230:519-527.

2. Faria AV, Reis F, Zanardi VA, Menezes JR, Cendes F. The pattern of proton magnetic resonance spectroscopy in non-neoplastic encephalic lesions. Arq Neuropsiquiatr 2004;62:429-436.

3. Siegal JA, Cacayorin ED, Nassif AS, et al. Cerebral mucormycosis: proton MR spectroscopy and MR imaging. Magn Reson Imaging 2000;18:915-920.

4. Sudhakar KV, Agrawal S, Rashid MR, Hussain N, Hussain M, Grupta RK. MRI demonstration of hemorrhage in the wall of a brain abscess: possible implications for diagnosis and management. Neuroradiology 2001;43:218-222.

5. Meyerand ME, Pipas JM, Mamourian A, Tosteson TD, Dunn JF. Classification of biopsy-confirmed brain tumors using single-voxel MR spectroscopy. Am J Neuroradiol 1999;20:117-123.

6. Kaminogo M, Ishimaru H, Morikawa M, Suzuki Y, Shibata S. Proton MR spectroscopy and diffusion-weighted MR imaging for the diagnosis of intracranial tuberculomas: report of two cases. Neurol Res 2002;24:537543.

7. Noguchi K, Watanabe N, Nagaoshi T, et al. Role of diffusion-weighted echo-planar MRI in distinguishing between brain abscess and tumour: a preliminary report. Neuroradiology 1999;41:171-174.

8. Kim YJ, Chang KH, Song IC, et al. Brain abscess and necrotic or cystic brain tumor: discrimination with signal intensity on diffusion-weighted MR imaging. Am J Roentgenol 1998;171:1487-1490.

9. Lai PH, Ho JT, Chen WL, et al. Brain abscess and necrotic brain tumor: discrimination with proton MR spectroscopy and diffusion-weighted imaging. Am J Neuroradiol 2002;23:1369-1377.

10. Desprechins B, Stadnik T, Koerts G, Shabana W, Breucq C, Osteaux M. Use of diffusion weighted NMR imaging in differential diagnosis between intracerebral necrotic tumors and cerebral abscesses. Am J Neu- roradiol 1999;20:1252-1257.

11. Mishra AM, Gupta RK, Jaggi RS, et al. Role of diffusion-weighted imaging and in vivo proton magnetic resonance spectroscopy in the differential diagnosis of ring-enhancing intracranial cystic mass lesions. J Comput Assist Tomogr 2004;28:540-547.

12. Tsui EYK, Chan JH, Cheung YK, Lai D KF, Fong SHN. Evaluation of cerebral abscesses by diffusion-weighted MR imaging and MR spectroscopy. Comput Med Imag Graph 2002;26:347-351.

13. Faria AV, Dabus GC, Zanardi VA, Cendes F. Proton magnetic resonance spectroscopy and magnetic resonance imaging findings in a patient with central nervous system paracoccidioidomycosis. J Neuroimag 2004;14:377-379.

14. Castillo M, Kwock L, Mukherji SK. Clinical applications of proton MR spectroscopy. Am J Neuroradiol 1996;17:1-15.

15. Chang L, Cornford ME, Chiang FL, Ernst TM, Sun NCJ, Miller BL. Radiologic-pathologic correlation cerebral toxoplasmosis and lymphoma in AIDS. Am J Neuroradiol 1995;16:1653-1663.

16. Poptani H, Gupta RK, Jain VK, Roy R, Pandey R. Cystic intracranial mass lesions: possible role of in vivo MR spectroscopy in its differential diagnosis. Magn Reson Imaging 1995;13:1019-1029.

17. Martinez-Perez I, Moreno A, Alonso J, et al. Diagnosis of brain abscess by magnetic resonance spectroscopy: report of two cases. J Neurosurg 1997;86:708-713.

18. Rémy C, Grand S, Laý ES, et al. 1H MRS of human brain abscesses in vivo and in vitro. Magn Reson Med 1995;34:508-514.

19. May GL, Sztelma K, Sorrell TC, Mountford CE. Comparison of human polymorphonuclear leukocytes from peripheral blood and purulent exudates by high resolution 1H MRS. Magn Reson Med 1991;19:191-198.

20. Burtscher IM, Holta S. Case report in vivo proton MR spectroscopy of untreated and treated brain abscesses. Am J Neuroradiol 1999;20:1049-1053.

21. Soto-Hernandez JL, Moreno-Andrade T, Góngora-Rivera F, RamírezCrescencio MA. Case report: Nocardia abscess during treatment of brain toxoplasmosis in a patient with aids, utility of proton MR spectroscopy and diffusion-weighted imaging in diagnosis. Clin Neurol Neurosurg 2006;108:493-498

22. Himmelreich U, Accurso R, Malik R, et al. Identification of Staphylococcus aureus brain abscesses: rat and human studies with $1 \mathrm{H}$ MR spectroscopy. Radiology 2005;236:261-270.

23. Harada M, Tanouchi M, Miyoshi H, Nishitani H, Kannuki S. Brain abscess observed by localized proton magnetic resonance spectroscopy. Magn Reson Imaging 1994;12:1269-1274.

24. Phillips KD, Tearle PV, Willis AT. Rapid diagnosis of anaerobic infections by gas-liquid chromatography of clinical material. J Clin Pathol 1976;29:428-432.

25. Gorbach SL, Mayhew JW, Bartlett JG, Thadepalli H, Onderdonk AB. Rapid diagnosis of anaerobic infection by direct gas-liquid chromatography of clinical specimens. J Clin Invest 1976;57:478-484.

26. Pandit S, Lin A, Gahbauner H, Libertin CR, Erdogan B. MR spectroscopy in neurocysticercosis. J Comput Assist Tomogr 2001;25:950-952.

27. Lai PH, Li KT, Hsu SS, et al. Pyogenic brain abscess: findings from in vivo 1.5-T and 11.7-T in vitro proton MR spectroscopy. Am J Neuroradiol 2005;26:279-288.

28. Kim SH, Chang KH, Song IC, et al. Brain abscess and brain tumor: discrimination with in vivo H-1 MR spectroscopy. Radiology 1997;204:239-245.

29. Stryer L. Citric acid cycle. In Stryer L (Ed). Biochemistry, 4.Ed. New York, NY: Freeman 1995:509-514.

30. Akutsu H, Matsumura A, Isobe T, Anno I, Takano S, Itai Y, Nose T. Chronological change of brain abscess in $1 \mathrm{H}$ magnetic resonance spectroscopy. Neuroradiology 2002;44:574-578. 